Editor's Note: These short reviews of a recent paper in the Journal, written exclusively by graduate students or postdoctoral fellows, are intended to mimic the journal clubs that exist in your own departments or institutions. For more information on the format and purpose of the Journal Club, please see http://www.jneurosci.org/misc/ifa_features.shtml.

\title{
Amyloid Plaques and Amyloid- $\beta$ Oligomers: An Ongoing Debate
}

\author{
Sylvain Lesné and Linda Kotilinek \\ Department of Neurology, University of Minnesota, Minneapolis, Minnesota 55455 \\ Review of Hartman et al. (http://www.jneurosci.org/cgi/content/full/25/26/6213)
}

Amyloid- $\beta$ (A $\beta)$ peptides, which accumulate in Alzheimer's disease (AD), are mainly produced by neurons as a soluble protein that aggregates into insoluble amyloid plaques under specific conditions, notably aging. This feature of AD has been reproduced in numerous transgenic models (e.g., PDAPP) that overexpress mutant amyloid precursor protein (APP) (Games et al., 1995). Transgenic mice have been useful in better understanding the pathology of AD and in testing therapeutic strategies. In contrast to strategies targeting $\beta$ - or $\gamma$-secretase activity, immunotherapy could theoretically improve the cognitive status of $\mathrm{AD}$ patients without altering physiological $\mathrm{APP} / \mathrm{A} \beta$ function. In animal models, immunization reportedly lowers cerebral $A \beta$ levels and amyloid burden, in addition to improving memory deficits (Schenk, 2002). In the June 29, 2005 issue of The Journal of Neuroscience, Hartman et al. (2005) (http://www.jneurosci.org/cgi/ content/full/25/26/6213) sought to determine whether age-dependent cognitive decline in PDAPP mice is attributable to aggregated $A \beta$ accumulation and whether reducing $A \beta$ deposition would improve learning and restore synaptic plasticity.

To assess learning, the authors used the Morris water maze. This water maze is

Received Aug. 3, 2005; revised Aug. 17, 2005; accepted Aug. 26, 2005. Correspondence should be addressed to Sylvain Lesné, Department of Neurology, University of Minnesota, Minneapolis, MN 55455. E-mail: lesne002@tc.umn.edu.

DOI:10.1523/JNEUROSCI.3246-05.2005

Copyright $\odot$ 2005 Society for Neuroscience $\quad$ 0270-6474/05/259319-02\$15.00/0 widely used to determine cognitive status in transgenic mice modeling $\mathrm{AD}$ and to measure the effects of prospective therapies. This swim test is used to assess hippocampal-dependent memory, but it is also sensitive to other memory systems, including procedural learning. In addition, performance depends highly on genetic background and environmental factors (Wolfer and Lipp, 2000). Thus, although simple in principle, the water maze is complex with regard to experimental design and data interpretation. Appropriately, Hartman et al. (2005) distinguished between an age-independent and age-dependent deficit in PDAPP mice on a pure $\mathrm{C} 57 \mathrm{BL} / 6$ background [Hartman et al. (2005), their Figs. 1-3 (http://www. jneurosci.org/cgi/content/full/25/26/6213/ FIG1, http://www.jneurosci.org/cgi/ content/full/25/26/6213/FIG2, http:// www.jneurosci.org/cgi/content/full/25/ 26/6213/FIG3)]. The observed early learning deficit was attributed to mutant APP overexpression, although it would have been helpful to compare wild-type (WT) APP transgenic mice with equivalent protein expression levels to exclude nonspecific transgene effects. The authors moved the hidden platform location each week and thus incorporated a switching task. Contrary to WT littermates, PDAPP mice failed to display a spatial bias for platform location during probe trials, suggesting that WT and PDAPP mice may use different memory systems or strategies to solve the task (Wolfer and Lipp, 2000). Alternatively, as the authors sug- gest, performing probe trials at shorter intervals after the final training trial would have improved the performance of PDAPP mice.

The authors hypothesized that $\mathrm{A} \beta$ accumulation was responsible for the agedependent impairment in C57BL/6PDAPP mice and sought to test this postulate by evaluating total $A \beta$ immunoreactivity, $\mathrm{A} \beta$ species levels, and conformations. ELISAs were used to quantify A $\beta$ levels. Reliable and sensitive, $A \beta$ ELISAs are useful in studying $A \beta$ metabolism, although soluble oligomeric $\mathrm{A} \beta$ species and fibrillar species are not detected by such assays (Stenh et al., 2005). Plaque load (diffuse and dense core) was estimated by immunohistochemistry and by thioflavine-S staining for $\beta$-sheet pleated structures. Because $\mathrm{A} \beta$ deposition starts between 6 and 9 months of age in PDAPP mice (Games et al., 1995), no plaques were found in young animals. Amyloid burden and thioflavine S-positive deposits were slightly elevated in middle-aged PDAPP mice and reached $\sim 25 \%$ of the hippocampal area in old mice, coinciding with the onset of agedependent cognitive impairment [Hartman et al. (2005), their Fig. 4 (http:// www.jneurosci.org/cgi/content/full/25/26/ $6213 /$ FIG4)]. These observations were confirmed by A $\beta$ ELISAs for both soluble and insoluble $\mathrm{A} \beta_{40}$ and $\mathrm{A} \beta_{42}$ [Hartman et al. (2005), their Table 1 (http://www. jneurosci.org/cgi/content/full/25/26/6213/ TBL1)].

The authors postulated that immunization with the $\mathrm{A} \beta$ antibody $10 \mathrm{D} 5$ and a 
subsequent modulation of amyloid deposition would restore learning in PDAPP mice [Hartman et al. (2005), their Fig. 5 (http://www.jneurosci.org/cgi/content/ full/25/26/6213/FIG5)]. Despite using a different behavioral testing protocol, 10D5 administration partially restored cognitive function. Amyloid burden was also reduced by $\sim 50 \%$ and plasma $\mathrm{A} \beta$ levels were dramatically increased [Hartman et al. (2005), their Fig. 6 (http:// www.jneurosci.org/cgi/content/full/25/ $26 / 6213 /$ FIG6)], suggesting that $A \beta$ species were cleared from the brain. Interestingly, $A \beta$ ELISAs confirmed the augmentation of plasma $\mathrm{A} \beta$, but parenchymal levels of all $\mathrm{A} \beta_{1-\mathrm{x}}$ species were unaltered [Hartman et al. (2005), their Table 2 (http://www.jneurosci.org/cgi/content/ full/25/26/6213/TBL2)]. Based on these findings, the authors concluded that amyloid plaques contribute to the learning deficits (Fig. 1). The discrepancy between amyloid burden and $\mathrm{A} \beta$ ELISA levels is surprising because parenchymal monomeric $A \beta$ levels might be expected to change after immunotherapy. Moreover, the biochemical methodology used (i.e., non-conformational-specific $\mathrm{A} \beta$ antibodies for both ELISAs and vaccination paradigms) cannot discriminate between effects caused by soluble $A \beta$ oligomers and $\mathrm{A} \beta$ fibrils because it is likely that 10D5 detects multiple $\mathrm{A} \beta$ conformations. Using the $\mathrm{A} \beta$ oligomer-specific A11 antiserum (Biosource, Camarillo, CA) would be useful to quantify $A \beta$ oligomers across ages in PDAPP mice, as would a comparison of 10D5- and A11-mediated immunotherapy. In addition, if 10D5 could rescue learning deficits in young mice (when plaques are absent), this would provide additional support for the postulate that $\mathrm{A} \beta$ burden, not soluble $\mathrm{A} \beta \mathrm{s}$, is responsible for the age-dependent behavioral alterations. Biochemical and histological assessments of the effects of 10D5 were performed after 4-8 weeks of treatment. Therefore, caution is warranted in relat-

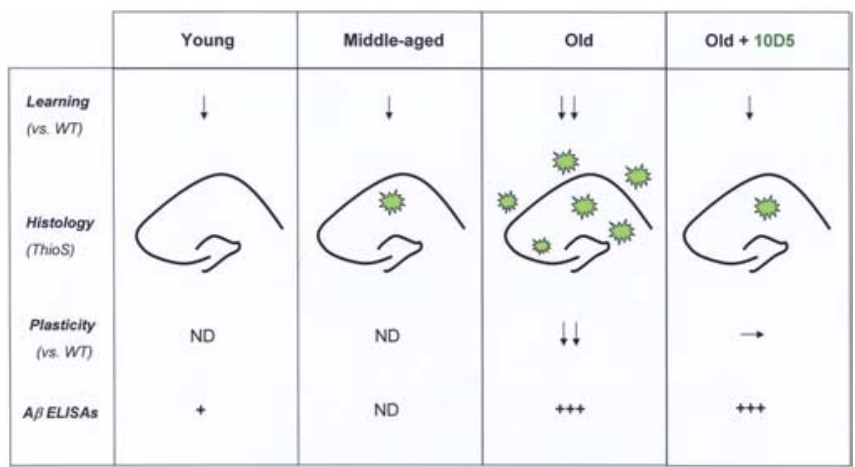

Figure 1. Summary of the behavioral, neuropathological, and functional characterization of C57BL/6 -PDAPP mice. ND, Not determined; $\downarrow$, lower than WT; $\rightarrow$, equivalent to WT; + ,low; +++ , high; green areas indicate thioflavine-S (ThioS)-positive A $\beta$ deposit.

ing these changes to the subacute ( $5 \mathrm{~d}$ of 10D5) improvements in behavior.

The authors also determined that immunization restored one measure of neuronal function, long-term potentiation (LTP) [Hartman et al. (2005), their Fig. 7 (http://www.jneurosci.org/cgi/content/ full/25/26/6213/FIG7)]. At $1 \mathrm{~h}$ after stimulation, hippocampal LTP was sixfold lower in old PDAPP animals compared with WT mice. In contrast, 10D5-treated PDAPP mice showed LTP similar to controls. Although the authors conclude that " $\mathrm{A} \beta$ is contributing to functional abnormalities in the PDAPP mice," $\mathrm{A} \beta$ oligomers inhibit LTP, a phenomenon that can be rescued by immunotherapy (Klyubin et al., 2005). Thus the possibility that 10D5 administration reduced $\mathrm{A} \beta$ dimers and trimers cannot be excluded. In sum, Hartman et al. (2005) demonstrated that PDAPP mice on a pure genetic background display age-independent and agedependent cognitive deficits, the latter coinciding with amyloid deposition. Immunotherapy partially restored cognitive function and lowered amyloid deposition. The contribution of oligomeric $A \beta$ species to this learning deficit was not specifically addressed, and may be of interest in future studies.

\section{References}

Games D, Adams D, Alessandrini R, Barbour R, Berthelette P, Blackwell C, Carr T, Clemens J, Donaldson T, Gillespie F, Guido T, Hagoplan S, Johnson-Wood K, Khan K, Lee M, Leibowitz P, Lieberburg I, Little S, Masliah E, McConlogue L, et al. (1995) Alzheimer-type neuropathology in transgenic mice overexpressing V717F beta-amyloid precursor protein. Nature 373:523-527.

Hartman RE, Izumi Y, Bales KR, Paul SM, Wozniak DF, Holtzman DM (2005) Treatment with an amyloid- $\beta$ antibody ameliorates plaque load, learning deficits, and hippocampal long-term potentiation in a mouse model of Alzheimer's disease. J Neurosci 25:6213-6220.

Klyubin I, Walsh DM, Lemere CA, Cullen WK, Shankar GM, Betts V, Spooner ET, Jiang L, Anwyl R, Selkoe DJ, Rowan MJ (2005) Amyloid beta protein immunotherapy neutralizes Abeta oligomers that disrupt synaptic plasticity in vivo. Nat Med 11:556-561.

Schenk D (2002) Amyloid-beta immunotherapy for Alzheimer's disease: the end of the beginning. Nat Rev Neurosci 3:824-828.

Stenh C, Englund H, Lord A, Johansson AS, Almeida CG, Gellerfors P, Greengard P, Gouras GK, Lannfelt L, Nilsson LN (2005) Amyloid-beta oligomers are inefficiently measured by enzyme-linked immunosorbent assay. Ann Neurol 58:147-150.

Wolfer DP, Lipp HP (2000) Dissecting the behaviour of transgenic mice: is it the mutation, the genetic background, or the environment? Exp Physiol 85:627-634. 